\title{
APLIKASI KITOSAN SEBAGAI ZAT ANTI BAKTERI PADA KAIN POLIESTER-SELULOSA DENGAN CARA PERENDAMAN
}

\author{
AFFIXATION OF CHITOSAN AS AN ANTIBACTERIAL AGENT ONTO \\ POLYESTER-CELLULOSE FABRICS USING EXHAUST METHOD
}

\author{
Wiwin Winiati, Cica Kasipah, Wulan Septiani, \\ Eva Novarini, Rizka Yulina
}

\author{
Balai Besar Tekstil, Jalan Jenderal Ahmad Yani No. 390 Bandung \\ E-mail: texirdti@bdg.centrin.net.id
}

Tanggal diterima: 22 Juli 2016, direvisi: 25 Oktober 2016, disetujui terbit: 3 November 2016

\begin{abstract}
ABSTRAK
Tujuan penelitian ini adalah membubuhkan kitosan pada kain poliester-selulosa (poliester-kapas/rayon) yang berupa kain grey dan kain yang telah diberi warna untuk mendapatkan kain poliester-selulosa yang mempunyai sifat antibakteri. Kain yang digunakan adalah poliester-kapas 65:35 berupa kain grey dan kain loreng dan poliester-rayon 70:30 yang berupa kain grey dan kain hijau AD. Aplikasi kitosan dilakukan dengan cara perendaman dengan penambahan senyawa natrium periodat sebagai oksidator. Analisa gugus fungsi dengan FTIR (fourier transform infra red) menunjukkan bahwa kitosan dengan gugus $-\mathrm{NH}_{2}$ dan $-\mathrm{OH}$ sebagai gugus aktifnya telah berikatan dengan poliester yang diperlihatkan dengan terjadinya peningkatan serapan gugus $\mathrm{C}=\mathrm{N}$ dan gugus $\mathrm{C}-\mathrm{O}$, serta penurunan gugus $\mathrm{C}=\mathrm{O}$ dari ester yang menunjukkan terjadi ikatan poliester dengan kitosan; dan peningkatan serapan pada bilangan gelombang $1641 \mathrm{~cm}^{-1}$ menunjukkan terjadinya ikatan antara aldehid dan kitosan yang menunjukkan terjadinya fiksasi kitosan pada selulosa (kapas dan rayon). Fiksasi kitosan pada kain poliester-selulosa yang berupa kain grey dan kain yang telah diberi warna telah berhasil memberikan sifat antibakteri pada kain, tidak mengakibatkan terjadinya kerusakan pada serat poliester maupun serat rayon/kapas pada kain, dan tidak mengakibatkan kerusakan/penurunan ketuaan warna pada kain yang telah diberi warna, bahkan semakin banyak kitosan yang diberikan akan meningkatkan ketuaan warna-warna tersebut.
\end{abstract}

Kata kunci: kitosan, antibakteri, poliester-selulosa, perendaman

\section{ABSTRACT}

This research was addressed to affix chitosan to polyester-cotton/rayon fabrics in the form of grey fabrics and dyed/printed fabrics in order to get an antibacterial polyester-cotton/rayon fabrics. Polyester-cotton 65:35 and polyester-rayon 70:30 as a grey fabric and after dyed/printed to be a military uniform are used. Affixation of chitosan was done using exhaust method with addition of sodiumperiodate as an oxidator. FTIR (fourier transform infra red) analysis showed increasing absorbtion of $C=N$ and $C$-O functional groups, and decreasing absorbtion of $\mathrm{C}=\mathrm{O}$ functional group indicated that chitosan active functional groups, $-\mathrm{NH}_{2}$ and $-\mathrm{OH}$, have been bonded into polyester structure; whereas affixation of chitosan into cellulose was indicated by increasing of absorption at 1641 $\mathrm{cm}^{-1}$. The affixation of chitosan into polyester-cotton/rayon as a grey fabric and after dyed/printed have yielded a good antibacterial properties, without any breakage of polyester as well as cellulose fibers and did't decrease their colour value, infact the increasing of chitosan added has yielded the slightly increasing on the depth of colour.

Keywords: chitosan, antibacterial, polyester-celullose, exhaust

\section{PENDAHULUAN}

Poliester merupakan tempat tinggal yang baik bagi bakteri micrococcus, bakteri Staphylococcus (bakteri gram positif yang hidup di ketiak manusia) ditemukan pada poliester dan kapas. ${ }^{\mathbf{1 , 2}}$ Mikroba/bakteri tersebut memakan komponen dalam keringat manusia dan aktivitas bakteri ini akan menimbulkan bau. Timbulnya bau sangat tidak diinginkan terutama bagi pakaian.
Beberapa produsen telah membuat kain poliester yang lebih tidak ramah terhadap bakteri (tahan bakteri) dengan cara membubuhkan bahan antimikroba yaitu nanopartikel perak, $\mathrm{ZnO}$ nanorod atau triklosan pada kain poliester. ${ }^{2,3,4,5}$ Akan tetapi, penggunaan kedua bahan antimikroba tersebut banyak dikritik karena berpotensi menimbulkan efek negatif terhadap lingkungan, dan belum ada cukup data yang menjelaskan pengaruh bahan tersebut terhadap pemakainya. Salah satu alternatif 
bahan yang bersifat antibakteri adalah kitosan. Kitosan merupakan polimer alam yang dapat diperoleh dari kulit crustacea seperti udang, rajungan, kepiting, dan lobster. Kitosan adalah derivat $\mathrm{N}$-asetilglukosamina dari kitin yang banyak dijumpai di alam, kitin/kitosan merupakan bahan alam terbanyak kedua setelah selulosa. Sebagai biopolimer alam, kitosan mempunyai sifat biodegradabel. Dengan adanya kandungan gugus amina primer yang bersifat kationik, pada $\mathrm{pH}<6,5$ kitosan yang berada dalam larutan akan bermuatan positif sehingga kitosan merupakan polimer polikationik, kitosan merupakan satu-satunya polisakarida kationik. Semua jaringan tubuh memiliki muatan negatif, sehingga kitosan yang membawa muatan positif dapat tertarik ke jaringan tubuh, kulit, tulang dan rambut. Sedangkan permukaan luar tubuh mikroba bermuatan positif. Hal ini menyebabkan kitosan mempunyai sifat menghambat aktifitas mikroba (anti bacterial activity), ${ }^{\mathbf{6 , 7 , 9}}$ sehingga kitosan juga dinyatakan mempunyai sifat antibakteri. Beberapa mekanisme yang menjelaskan sifat antibakteri kitosan yaitu mekanisme pertama menyatakan bahwa sifat polikationik kitosan yang berinteraksi dengan gugus anion dalam permukaan sel, menyebabkan terbentuknya lapisan yang impermeable (kedap) disekitar sel sehingga menghalangi perpindahan larutan esensial. Mekanisme kedua melibatkan inhibisi RNA dan protein yang disintesis melalui penetrasi ke dalam inti sel. Liu, N. dan kawankawan. (2006), ${ }^{\mathbf{1 0}}$ mengamati kitosan oligomer dengan BM 5 - $8 \mathrm{kDa}$ di dalam sel E.coli dan menunjukkan aktifitas antibakteri yang baik. Mekanisme lain, kitosan menghambat pertumbuhan mikroba dengan cara bertindak sebagai chelating agent yang menyebabkan logam-logam, trace element atau nutrisi esensial tidak tersedia untuk pertumbuhan normal mikroba. ${ }^{7,11}$

Teknik mengaplikasikan zat antibakteri ke dalam tekstil dapat dilakukan dengan berbagai cara bergantung pada sifat zat antibakteri dan jenis serat tekstilnya. Untuk aplikasi pada serat sintetik, zat antibakteri dapat ditambahkan ke dalam bahan polimer sebelum proses pembuatan serat. Cara ini merupakan yang terbaik karena zat antibakteri terikat secara fisik di dalam serat sehingga memiliki ketahanan yang cukup kuat. Cara lain adalah dengan pelapisan, yaitu cara pad-dry-cure yang juga pernah dilakukan dalam mengaplikasikan zat antibakteri seperti triklosan baik pada kain dari serat alam maupun serat sintetik. Cara berikutnya adalah dengan melakukan modifikasi permukaan melalui pembentukan jaringan interpenetrasi. ${ }^{12,13}$ Immobilisasi poliamida ke dalam polietilenatereftalat (PET) melalui pembentukan jaringan interpenetrasi, telah terbukti menghasilkan biosida yang efektif. ${ }^{14}$ Cara lain yang banyak dikembangkan adalah metoda kimia, yaitu dengan melakukan grafting polymerization, pembentukan ikatan kovalen dan ion-exchange/chelation. Metoda kimia dengan cara pembentukan ikatan kovalen dapat dilakukan pada serat alam dan serat regenerasi seperti katun, wool dan viscose. Karena beragamnya kondisi reaksi grafting, maka hanya reagen yang reaktif tinggi seperti aldehida, gugus alkil terhalogenasi, epoxida, asilklorida yang dapat digunakan untuk modifikasi kovalen. ${ }^{12,13,15,16}$

Pada penelitian terdahulu, ${ }^{17}$ telah dilakukan cara modifikasi kovalen pada serat kapas yang merupakan serat selulosa dengan pembentukan gugus aldehida yang dilakukan dengan menggunakan oksidator natrium/kalium periodat. Selanjutnya gugus aldehida yang terbentuk akan berikatan dengan gugus amina pada kitosan yang akan menghasilkan fiksasi kitosan pada serat kapas. ${ }^{17}$ Reaksi yang terjadi pada cara ini disajikan pada Gambar 1.

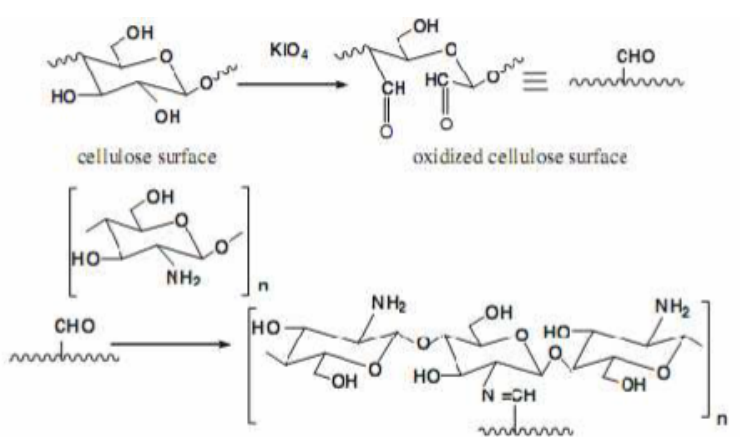

Gambar 1. Reaksi fiksasi kitosan pada selulosa ${ }^{\mathbf{1 3}}$

Pada penelitian ini metoda kimia dengan cara modifikasi kovalen menggunakan oksidator natrium/kalium periodat melalui proses perendaman (exhaust) dicoba dilakukan pada kain poliesterkapas/rayon dengan harapan kitosan tidak hanya berikatan dengan selulosa tetapi juga dengan gugus ester dalam poliester. Sifat antibakteri kitosan akan lebih baik untuk berat molekul (BM) kitosan yang lebih rendah. Untuk menurunkan BM kitosan dilakukan depolimerisasi kitosan cara fisik dengan memberi radiasi, yaitu radiasi gelombang mikro menggunakan microwave oven. ${ }^{18}$ 
Aplikasi kitosan sebagai zat anti bakteri pada kain poliester-selulosa dengan cara perendaman (Wiwin Winiati, Cica Kasipah, Wulan Septiani, Eva Novarini, Rizka Yulina)

\section{METODE}

Alur penelitian dilakukan menurut diagram seperti ditunjukkan pada Gambar 2.

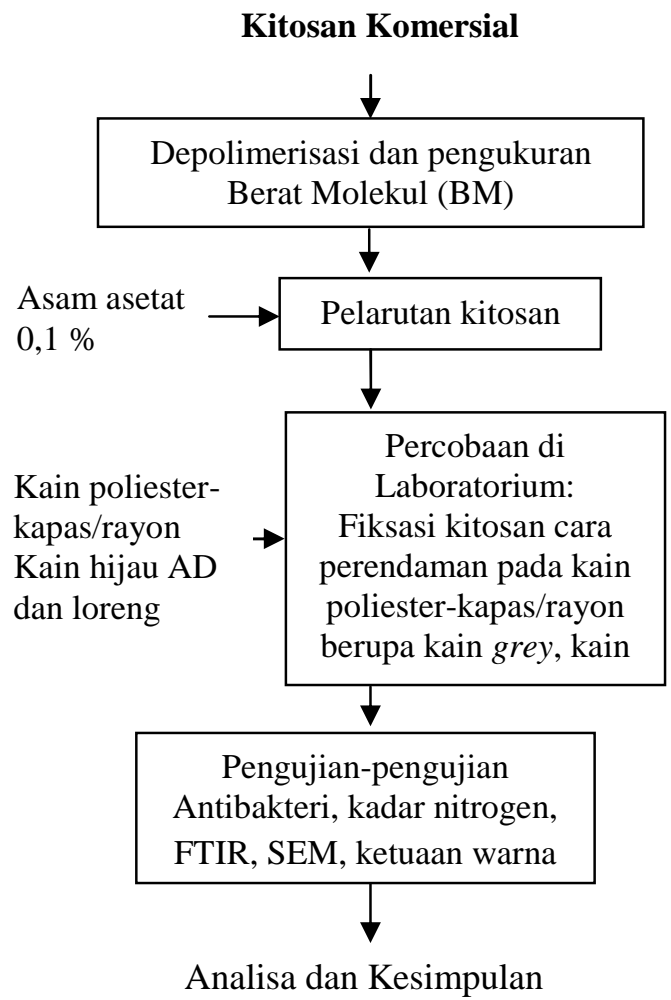

Gambar 2. Alur penelitian

\section{Bahan}

Kain yang digunakan adalah kain grey poliester-rayon 70:30, kain grey poliester-kapas 65:35, kain militer hijau AD sebagai kain poliesterrayon 70:30 yang telah dicelup dan kain loreng sebagai kain poliester-kapas 65:35 yang telah diprinting. Kitosan teknis diperoleh dari PT. Biotech Surindo Cirebon. Bahan kimia grade teknis diperoleh dari pasaran, dan bahan kimia grade p.a diperoleh dari Merck

\section{Peralatan}

- Peralatan yang digunakan di laboratorium meliputi mesin exhaust, microwave oven.

- Pengukuran viskositas larutan kitosan dilakukan dengan menggunakan alat Brookfield viscometer, analisa gugus fungsi dilakukan dengan cara FTIR menggunakan FTIR merek Shimadzu Prestige, morfologi kain diamati dengan alat Scanning Electron Microscope (SEM) merek JEOL JSM6510/LV/A/LA.

\section{Cara}

- Pada kitosan teknis dengan berat molekul 171.000 Da dilakukan depolimerisasi dengan memberi gelombang mikro menggunakan microwave oven hingga diperoleh kitosan dengan berat molekul sekitar $70.000 \mathrm{Da}^{18}$

- Berat molekul kitosan diukur melalui pengukuran viskositas larutan kitosan, dan BM dihitung dengan menggunakan persamaan Mark Houwink (Persamaan 1). ${ }^{\mathbf{1 0}}$

$$
\left[\eta=K \cdot M^{\mathrm{a}}\right]
$$

untuk

$$
\begin{aligned}
& \mathrm{K}=1,64 \times 10^{-30} \times \mathrm{DD}^{14} \\
& \mathrm{a}=-1,02 \times 10^{-2} \mathrm{DD}+1,82 \\
& \text { DD adalah derajat deasetilasi } \\
& \text { dalam persen }
\end{aligned}
$$

- Dibuat larutan kitosan 1\% (b/v) dalam asam asetat $1 \%(\mathrm{v} / \mathrm{v})$ untuk kitosan BM $171.000 \mathrm{Da}$ dan BM 70.000 Da.

- Aplikasi kitosan pada poliester-rayon/kapas dilakukan melalui cara kimia yaitu diawali proses oksidasi menggunakan natrium periodat $(50 \mathrm{mg} / 100 \mathrm{ml}$ ), dilanjutkan reaksi dengan gugus amina dari kitosan. Proses dilakukan satu tahap dengan cara perendaman menggunakan mesin ekshaus. ${ }^{17}$

- Kain-kain yang telah difiksasi kitosan dicuci dengan larutan buffer $\mathrm{pH}$ 5,0 pada temperatur $40^{\circ} \mathrm{C}$ lalu dikeringkan.

- Keberhasilan fiksasi kitosan pada kain poliester-rayon/kapas dievaluasi dengan melakukan pengujian dengan alat FTIR untuk mengetahui terjadinya ikatan kimia antara kapas/rayon dan poliester dengan kitosan. ${ }^{19}$ Setiap pengujian FTIR dilakukan dengan jumlah sampel yang sama. Pengujian dengan alat Scanning Electron Microsope (SEM) dilakukan untuk mengetahui morfologi serat, dan pengujian ketahanan bakteri terhadap kain yang dihasilkan dilakukan dengan menggunakan standar AATCC 147-2004. ${ }^{\mathbf{2 0}}$

- Untuk mengetahui pengaruh pemberian kitosan terhadap warna kain dilakukan pengujian ketuaan warna dengan cara CIELab: D65-10 terhadap kain hijau $\mathrm{AD}$ dan kain loreng sebelum dan setelah dilakukan fiksasi kitosan. Pengujian ketuaan warna dilakukan dengan membuat kurva reflektansi terhadap panjang gelombang untuk kain hijau $\mathrm{AD}$ dan kain loreng. Perhitungan kuantitatif ketuaan warna dilakukan dengan menggunakan persamaan Kubelka Munk (Persamaan 2) untuk menghitung K/S. 


$$
\frac{K}{S}=\frac{(1-R)^{2}}{2 R}-\frac{\left(1-R_{o}\right)^{2}}{2 R}
$$

Dengan :

$$
\begin{array}{ll}
K / S & : \text { Konstanta Kubelka Munk } \\
K & : \text { Koefisien absorpsi } \\
S & : \text { Koefisien penghamburan cahaya } \\
R & : \text { Reflektansi kain berwarna } \\
R_{0} & : \text { Reflektansi kain putih }
\end{array}
$$

\section{HASIL DAN PEMBAHASAN}

\section{Data kitosan dan depolimerisasi kitosan}

Data kitosan yang digunakan diperoleh dari sertifikat produk yang dikeluarkan oleh produsen dan dari hasil pengukuran sebagai berikut.

- Warna putih kekuningan (off white)

- Ukuran partikel 20 - 30 \#

- Kadar air $<10 \%$

- Kadar abu < 1,5\%

- $\mathrm{pH} 7-8$

- Derajat deasetilasi sekitar 90\%

- Berat molekul 171.790

\section{Depolimerisasi kitosan}

Depolimerisasi kitosan awal BM 171.790 Da, menggunakan microwave oven dengan waktu 15 menit dan daya hingga 650 watt memberikan hasil kitosan dengan berat molekul mencapai sekitar $70.000 \mathrm{Da},{ }^{18}$ berat molekul dihitung dengan menggunakan persamaan 1 .

\section{Hasil uji FTIR}

Hasil uji FTIR kain grey poliester-rayon 70:30 sebelum dan setelah aplikasi kitosan untuk memudahkan pembandingan diberikan pada
Gambar 3, yang merupakan overlay dari spektrum FTIR kain grey (P:R=70:30) tanpa kitosan dan kain grey ( $\mathrm{P}: \mathrm{R}=70: 30$ ) dengan kitosan $1 \%$ (kedua spektrum ini yang memberikan nilai $\% \mathrm{~T}$ terhadap bilangan gelombang, tidak ditampilkan). Dari spektrum FTIR kain grey (P:R=70:30) tanpa kitosan dan kain grey ( $\mathrm{P}: \mathrm{R}=70: 30)$ dengan kitosan $1 \%$ diperoleh data $\% \mathrm{~T}$, dan dengan perhitungan $\mathrm{A}=$ $2-\log \% \mathrm{~T}$ diperoleh nilai absorbansi (A) untuk kain grey poliester-rayon 70:30 tanpa dan dengan penambahan kitosan, yang datanya diberikan pada Tabel 1.

Tabel 1. Nilai \% $\mathrm{T}$ dan Absorbansi (A) kain grey poliester-rayon 70:30

\begin{tabular}{cccccc}
\hline & & \multicolumn{2}{c}{ A } \\
\cline { 3 - 6 } No & $\lambda$, & Kain & Kain Grey & Kain & Kain Grey \\
& $\mathrm{cm}^{-1}$ & Grey P- & P-R 70:30 & Grey P- & P-R 70:30 \\
& & R & + kitosan & R & + kitosan \\
& & $70: 30$ & $1 \%$ & $70: 30$ & $1 \%$ \\
\hline 1 & 1714 & 28,97 & 24,80 & 0,538 & 0,605 \\
2 & 1409 & 37,40 & 32,45 & 0,427 & 0,489 \\
3 & 1240 & 26,92 & 20,04 & 0,570 & 0,698 \\
4 & 1097 & 20,14 & 14,80 & 0,696 & 0,830 \\
\hline
\end{tabular}

Dari data pada Tabel 1 terlihat bahwa penambahan kitosan pada kain poliester-rayon telah meningkatkan serapan (A) pada bilangan gelombang $1409 \mathrm{~cm}^{-1}$ dari vibrasi $\mathrm{C}=\mathrm{N}$ dan serapan pada bilangan gelombang $1240 \mathrm{~cm}^{-1}$ dan $1097 \mathrm{~cm}^{-1}$ dari vibrasi $\mathrm{C}-\mathrm{O}$, dan serapan pada bilangan gelombang $1714 \mathrm{~cm}^{-1}$ dari vibrasi $\mathrm{C}=\mathrm{O}$ dalam gugus ester. Hal ini menunjukkan bahwa kitosan dengan gugus $-\mathrm{NH}_{2}$ sebagai gugus aktifnya telah berikatan dengan poliester-rayon (selulosa). Kain grey poliester-rayon 70:30 merupakan kain yang digunakan untuk membuat kain hijau AD.

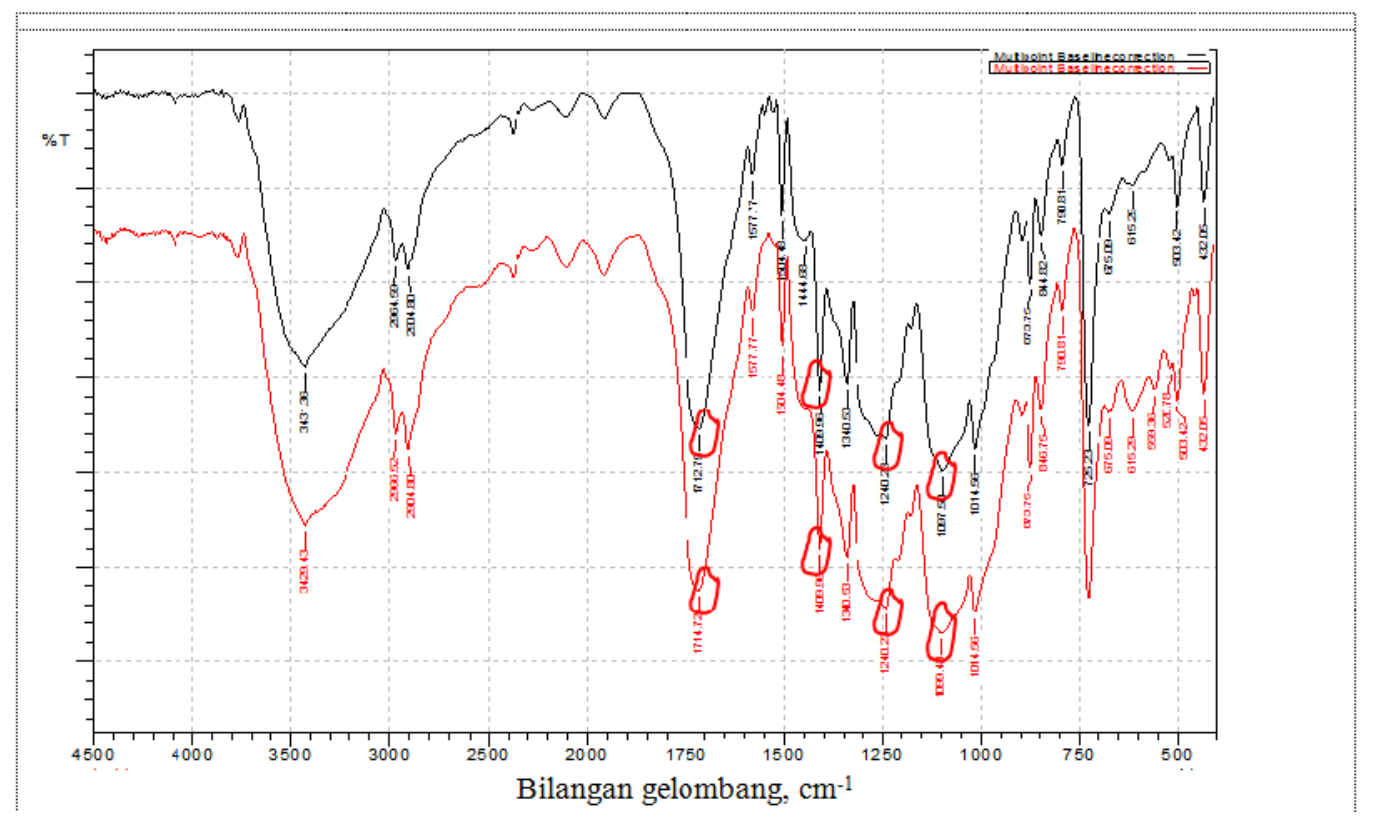

Gambar 3. Overlay Spektrum FTIR kain Grey (P:R=70:30) tanpa kitosan (hitam/atas), kain Grey (P:R=70:30) Kitosan 1\% (merah/bawah) 


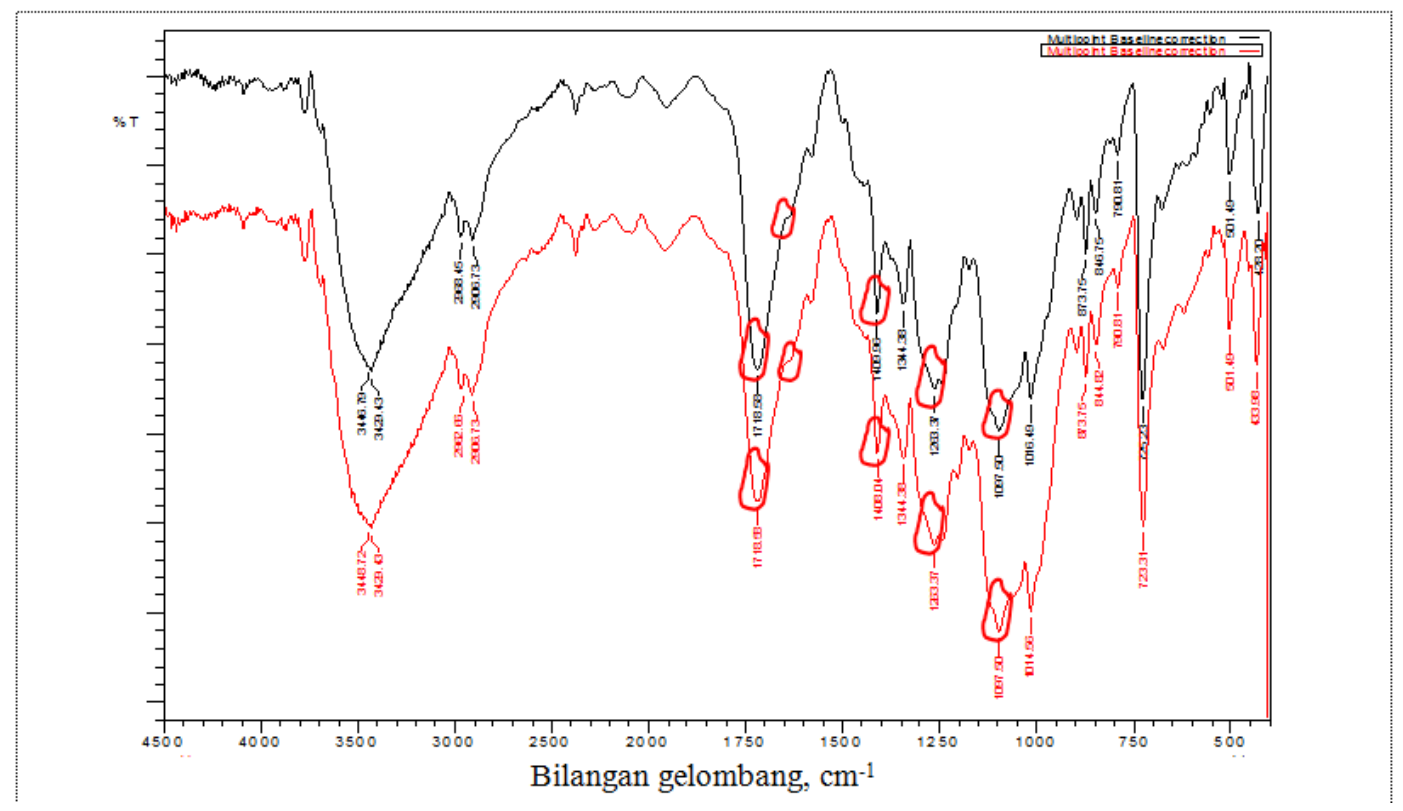

Gambar 4. Overlay Spektrum FTIR kain hijau AD (hitam/atas) dan kain hijau AD $1 \%$ kitosan (merah/bawah)

Hasil uji FTIR kain hijau AD sebelum dan setelah aplikasi kitosan overlay-nya diberikan pada Gambar 4. Dari spektrum FTIR diperoleh data \% T, dan dengan perhitungan $\mathrm{A}=2-\log \% \mathrm{~T}$ diperoleh nilai absorbansi (A) untuk kain grey hijau AD tanpa dan dengan penambahan kitosan, dengan data seperti ditunjukkan pada Tabel 2.

Data pada Tabel 2 memperlihatkan bahwa hal yang sama terjadi pada kain hijau $\mathrm{AD}$, dengan penambahan kitosan terjadi peningkatan serapan gugus $\mathrm{C}=\mathrm{N}$ dan gugus $\mathrm{C}-\mathrm{O}$, penurunan gugus $\mathrm{C}=\mathrm{O}$ dari ester, dan peningkatan serapan pada bilangan gelombang $1641 \mathrm{~cm}^{-1}$ yang menunjukkan terjadinya ikatan antara aldehid dan kitosan yang menunjukkan terjadinya fiksasi kitosan pada rayon/selulosa.

Hasil uji FTIR kain grey poliester-kapas 65:35 sebelum dan setelah aplikasi kitosan overlaynya diberikan pada Gambar 5. Dari spektrum FTIR diperoleh data $\% \mathrm{~T}$, dan dengan perhitungan $\mathrm{A}=2$ $\log \% \mathrm{~T}$ diperoleh nilai absorbansi (A) untuk kain grey poliester-kapas 65:35 tanpa dan dengan penambahan kitosan, yang datanya diberikan pada Tabel 3. Dari data pada Tabel 3 terlihat bahwa penambahan kitosan pada kain poliester-kapas telah meningkatkan serapan (A) pada bilangan gelombang $1409 \mathrm{~cm}^{-1}$ dari vibrasi $\mathrm{C}=\mathrm{N}$, serapan pada bilangan gelombang $1240 \mathrm{~cm}^{-1}$ dan $1097 \mathrm{~cm}^{-1}$ dari vibrasi $\mathrm{C}-\mathrm{O}$, dan serapan pada bilangan gelombang $1714 \mathrm{~cm}^{-1}$ dari vibrasi $\mathrm{C}=\mathrm{O}$ dalam gugus ester. Hal ini menunjukkan bahwa kitosan dengan gugus $-\mathrm{NH}_{2}$ sebagai gugus aktifnya telah berikatan dengan poliester-kapas.

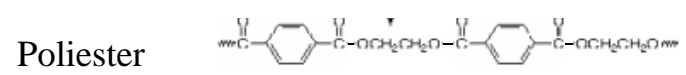
yang merupakan polimer sintetis dari asam tereftalat dan etilen glikol, dengan FTIR akan memberikan puncak-puncak pada bilangan gelombang $1750-1700 \mathrm{~cm}^{-1}$ untuk stretching vibrasi $\mathrm{C}=\mathrm{O}$ pada gugus ester, pada $1300-1000 \mathrm{~cm}^{-1}$ untuk stretching vibrasi $\mathrm{C}-\mathrm{O}$, sedangkan stretching vibrasi $\mathrm{C}=\mathrm{N}$ akan memberikan puncak pada bilangan gelombang 1430-1400 $\mathrm{cm}^{-1}$ dan stretching vibrasi N-H pada $1650-1515 \mathrm{~cm}^{-1}$. 19

Tabel 2. Nilai \% $\mathrm{T}$ dan Absorbansi (A) kain hijau $\mathrm{AD}$

\begin{tabular}{|c|c|c|c|c|c|}
\hline \multirow[b]{2}{*}{ No } & \multirow[b]{2}{*}{$\begin{array}{c}\lambda, \\
\mathrm{cm}^{-1}\end{array}$} & \multicolumn{2}{|c|}{$\% \mathrm{~T}$} & \multicolumn{2}{|c|}{ A } \\
\hline & & $\begin{array}{c}\text { Kain } \\
\text { Hijau } \\
\text { AD }\end{array}$ & $\begin{array}{c}\text { Kain } \\
\text { Hijau AD } \\
+ \text { kitosan } \\
1 \%\end{array}$ & $\begin{array}{c}\text { Kain } \\
\text { Hijau } \\
\text { AD }\end{array}$ & $\begin{array}{c}\text { Kain } \\
\text { Hijau AD } \\
+ \text { kitosan } \\
1 \%\end{array}$ \\
\hline 1 & 1718 & 67,24 & 67,84 & 0,172 & 0,168 \\
\hline 2 & 1641 & 84,14 & 82,79 & 0,075 & 0,082 \\
\hline 3 & 1409 & 73,48 & 73,21 & 0,133 & 0,135 \\
\hline 4 & 1263 & 65,06 & 62,94 & 0,186 & 0,201 \\
\hline 5 & 1097 & 60,31 & 53,26 & 0,220 & 0,274 \\
\hline
\end{tabular}

Tabel 3. Nilai \% $\mathrm{T}$ dan Absorbansi (A) kain grey poliester-kapas 65:35

\begin{tabular}{cccccc}
\hline & & \multicolumn{2}{c}{$\% \mathrm{~T}$} \\
\cline { 3 - 6 } No & $\lambda$, & Kain & Kain Grey & Kain & Kain Grey \\
& $\mathrm{cm}^{-1}$ & Grey P- & P-K 65:35 & Grey P- & P-K 65:35 \\
& & $\mathrm{K}$ & + kitosan & K & + kitosan \\
& & $65: 35$ & $1 \%$ & $65: 35$ & $1 \%$ \\
\hline 1 & 1714 & 26,85 & 15,46 & 0,571 & 0,810 \\
2 & 1409 & 36,07 & 21,31 & 0,442 & 0,671 \\
3 & 1240 & 23,75 & 11,42 & 0,624 & 0,942 \\
4 & 1097 & 17,40 & 7,23 & 0,759 & 1,101 \\
\hline
\end{tabular}




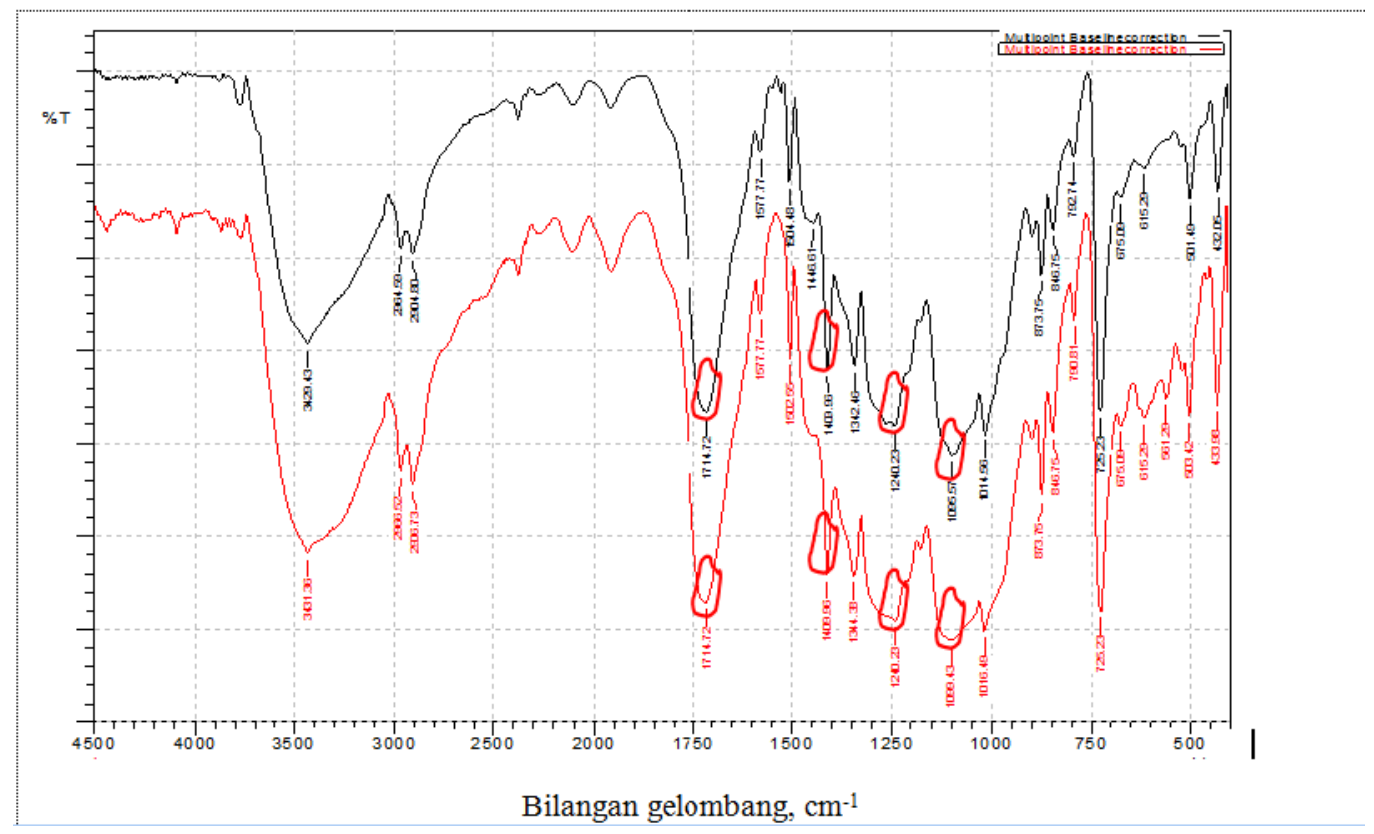

Gambar 5. Overlay Spektrum FTIR kain Grey (P:K=65:35) tanpa kitosan (hitam/atas), kain Grey Kitosan 1\% (P:K=65:35) (merah/bawah)

\section{Analisa Scanning Electron Microscope (SEM)}

Analisa SEM dilakukan untuk melihat apakah ada perbedaan antara struktur permukaan serat kapas, rayon dan poliester pada kain poliesterrayon (hijau $\mathrm{AD}$ ) dan kain poliester-kapas (kain loreng) yang telah mendapat fiksasi kitosan, dibandingkan terhadap struktur permukaan awal serat kapas, rayon dan poliester.
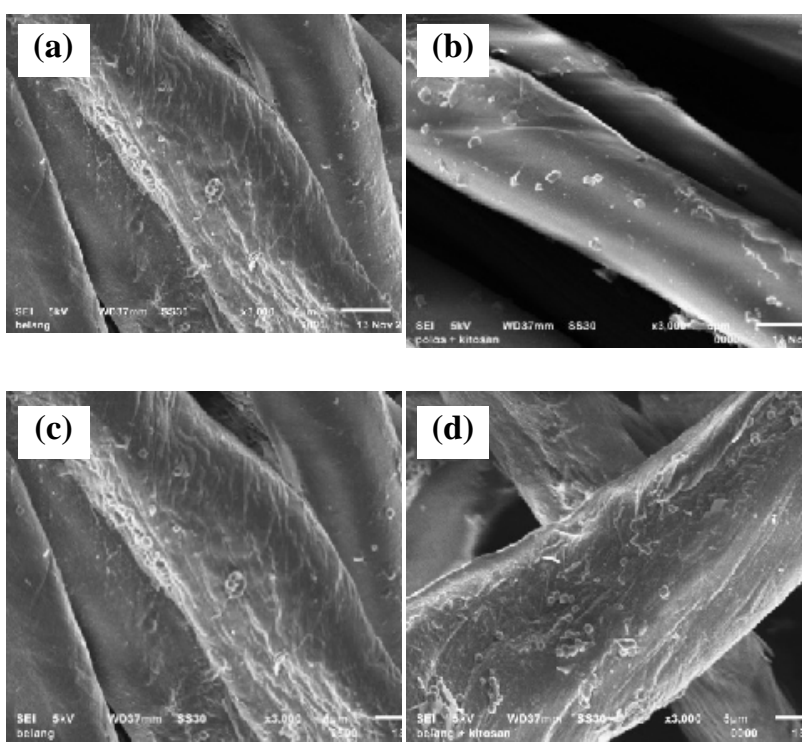

Gambar 6. Analisa SEM fiksasi kitosan pada kain Hijau AD dan Kain Loreng : a) Hijau, b) Hijau kitosan, c) Loreng, d) Loreng + kitosan.
Hasil citra SEM yang ditunjukkan pada Gambar 6 memperlihatkan bahwa tidak terjadi perbedaan struktur permukaan yang signifikan antara kain hijau $\mathrm{AD}$ dan kain loreng yang difiksasi kitosan terhadap kain hijau $\mathrm{AD}$ dan kain loreng semula yang menunjukkan tidak terjadi kerusakan pada serat kapas, rayon dan poliester akibat dari proses fiksasi kitosan.

\section{Hasil Uji Ketahanan Bakteri}

Uji ketahanan bakteri dilakukan terhadap kain hijau, kain loreng, kain grey poliester-kapas 65:35 dan poliester-rayon 70:30. Pengujian antibakteri dilakukan terhadap 2 jenis bakteri yaitu bakteri Escherichia Coli (E.Coli) dan bakteri Staphylococcus Aureus (S.Aureus), dengan menghitung reduksi pertumbuhan bakteri menggunakan persamaan 3, yang hasilnya disajikan pada Tabel 4.

Pengujian antibakteri: $\% \mathrm{R}=100 \underline{(\mathrm{A}-\mathrm{B})}$

$$
\mathrm{A}
$$

$\% \mathrm{R}=\%$ reduksi pertumbuhan bakteri.

$\mathrm{A}=$ Jumlah bakteri yang tumbuh pada sampel kain, diinkubasi 0 jam.

$\mathrm{B}=$ Jumlah bakteri yang tumbuh pada sampel kain setelah diinkubasi selama 48 jam.

Dari data pada Tabel 4 terlihat bahwa fiksasi kitosan $0,5 \%$ maupun $1,0 \%$ serta $2,0 \%$ dengan waktu fiksasi 45 menit memberikan kain hijau AD yang mempunyai ketahanan terhadap bakteri $E$. Coli pada inkubasi 48 jam mendekati 100\%, sedangkan ketahanan terhadap bakteri S.Aureus makin tinggi pemberian kitosan menghasilkan 
Tabel 4. Hasil uji ketahanan bakteri

\begin{tabular}{|c|c|c|c|c|c|c|}
\hline \multirow{3}{*}{ Sampel } & \multicolumn{6}{|c|}{ Jenis bakteri } \\
\hline & \multicolumn{3}{|c|}{ E.Coli } & \multicolumn{3}{|c|}{ S. Aureus } \\
\hline & $\begin{array}{l}\text { Blanko } \\
\text { Bakteri }\end{array}$ & $\begin{array}{c}\text { Sampel } \\
\text { Kain }\end{array}$ & $\% \mathrm{R}$ & $\begin{array}{l}\text { Blanko } \\
\text { Bakteri }\end{array}$ & $\begin{array}{c}\text { Sampel } \\
\text { Kain }\end{array}$ & $\% \mathrm{R}$ \\
\hline Hijau AD+K 0,5 & 530.000 .000 & 420.000 & 99,92 & 308.000 .000 & 75.600 .000 & 75,45 \\
\hline Hijau AD+K 1,0 & 530.000 .000 & 1.110 .000 & 99,79 & 308.000 .000 & 48.200 .000 & 84,35 \\
\hline $\mathrm{Hijau} \mathrm{AD}+\mathrm{K} 2,0$ & 530.000 .000 & 1.110 .000 & 99,79 & 308.000 .000 & 0 & 100,00 \\
\hline Loreng+K 0,5 & 530.000 .000 & 0 & 100,00 & 308.000 .000 & 47.600 .000 & 84,55 \\
\hline Loreng+K 1,0 & 530.000 .000 & 43.600 .000 & 91,77 & 308.000 .000 & 40.400 .000 & 86,88 \\
\hline PE-R + K 1,0 & 530.000 .000 & 0 & 100,00 & 308.000 .000 & 0 & 100,00 \\
\hline PE-R + K 2,0 & 530.000 .000 & 0 & 100,00 & 308.000 .000 & 0 & 100,00 \\
\hline PE-K + K 1,0 & 530.000 .000 & 0 & 100,00 & 308.000 .000 & 54.000 & 99,98 \\
\hline PE-K + K 2,0 & 530.000 .000 & 0 & 100,00 & 308.000 .000 & 82.000 & 99,97 \\
\hline
\end{tabular}

Keterangan: $\mathrm{K} 0,5=$ kitosan $0,5 \%$, dst

Tabel 5. Hasil uji kadar N-total

\begin{tabular}{lccccccc}
\hline \multicolumn{1}{c}{ Sampel } & $\begin{array}{c}\text { Berat } \\
\text { kain }(\mathbf{g})\end{array}$ & $\begin{array}{c}\mathbf{V ~ N a O H} \\
\mathbf{1}(\mathbf{m L})\end{array}$ & $\begin{array}{c}\mathbf{V ~ N a O H} \\
\mathbf{2}(\mathbf{m L})\end{array}$ & $\begin{array}{c}\text { V rata2 } \\
(\mathbf{m L})\end{array}$ & $\begin{array}{c}\text { V titrasi } \\
(\mathbf{V t})(\mathbf{m L})\end{array}$ & $\begin{array}{c}\mathbf{V} \text { destilasi } \\
(\mathbf{V d}),(\mathbf{m L})\end{array}$ & $\mathbf{\%} \mathbf{~ N}$ \\
\hline $\begin{array}{l}\text { Grey P:R 70:30 } \\
\text { Grey P:R 70:30 }\end{array}$ & 1,008 & 0,52 & 0,54 & 0,53 & 100 & 300 & 15,65 \\
+ Kitosan 1\% & 1,0043 & 0,65 & 0,67 & 0,66 & 100 & 300 & 27,73 \\
$\begin{array}{l}\text { Grey P:R 70:30 } \\
\text { + Kitosan 2\% }\end{array}$ & 1,0011 & 0,75 & 0,79 & 0,77 & 100 & 300 & 38,01 \\
$\begin{array}{l}\text { Grey P:K 65:35 } \\
\text { Grey P:K 65:35 }\end{array}$ & 1,0036 & 0,50 & 0,58 & 0,54 & 100 & 300 & 16,65 \\
+ Kitosan 1\% & 1,0019 & 0,76 & 0,75 & 0,76 & 100 & 300 & 36,59 \\
$\begin{array}{l}\text { Grey P:K 65:35 } \\
\text { + Kitosan 2\% }\end{array}$ & 1,0050 & 0,80 & 0,82 & 0,81 & 100 & 300 & 41,56 \\
\hline
\end{tabular}

ketahanan bakteri $S$. Aureus yang makin tinggi hingga dicapai ketahanan $100 \%$ dengan pemberian kitosan 2\%. Demikian pula untuk kain loreng, serta kain grey poliester-rayon maupun kain grey poliester-kapas sebagai bahan baku untuk pembuatan kain hijau AD dan kain loreng, fiksasi kitosan telah berhasil memberikan ketahanan kain terhadap bakteri E.coli dan bakteri S.Aureus hingga mendekati $100 \%$.

\section{Hasil uji kadar N-total}

Untuk mengetahui terjadinya fiksasi kitosan pada kain yang berupa kain campuran serat poliester-rayon dan poliester-kapas, selain dilakukan pengujian antibakteri terhadap bakteri E.coli dan bakteri S.Aureus, dilakukan pula pengujian kadar nitrogen $\mathrm{N}$-total dalam kain yang menunjukkan terjadinya ikatan gugus $\mathrm{NH}_{2}$ dari kitosan dengan serat. Hasil uji kadar N-total disajikan pada Tabel 5.

Dari data pada Tabel 5 terlihat bahwa fiksasi kitosan pada kain grey poliester-rayon 70:30, kain grey poliester-kapas 65:35, telah berhasil meningkatkan kadar $\mathrm{N}$-total, dan makin tinggi pemberian kitosan memberikan kadar N-total yang makin tinggi pula. Hal ini sesuai dengan hasil pengujian ketahanan bakteri E.coli dan bakteri S.Aureus terhadap kain grey poliester-rayon 70:30, kain grey poliester-kapas 65:35, yang menunjukkan terjadinya ikatan antara gugus gugus $\mathrm{NH}_{2}$ dari kitosan dengan serat.

\section{Hasil Uji Ketuaan Warna}

Ketuaan warna dihitung dengan menggunakan persamaan 2. Hasilnya untuk kain hijau AD disajikan pada Gambar 7, serta Tabel 6; dan untuk kain loreng pada Gambar 8, serta Tabel 7.

Dari kurva reflektansi pada Gambar 7 terlihat bahwa kurva \%R (\% reflektansi) kain hijau AD yang difiksasi kitosan dengan konsentrasi $0,5 \%$ sampai 2,0\% hampir berhimpit dengan kain hijau AD tanpa fiksasi kitosan. Bentuk kurva-kurva yang hampir berhimpit tersebut dengan karakteristik puncak pada panjang gelombang yang sama menunjukkan bahwa semuanya menghasilkan arah warna yang sama. Dari data pada Tabel 6 terlihat bahwa penambahan kitosan pada kain hijau $A D$ cenderung meningkatkan nilai $\mathrm{K} / \mathrm{S}$ yang berarti 
ketuaan warna cenderung meningkat. Hal ini cukup baik karena berarti pula proses fiksasi kitosan pada kain hijau AD tidak merusak warna hijau semula.

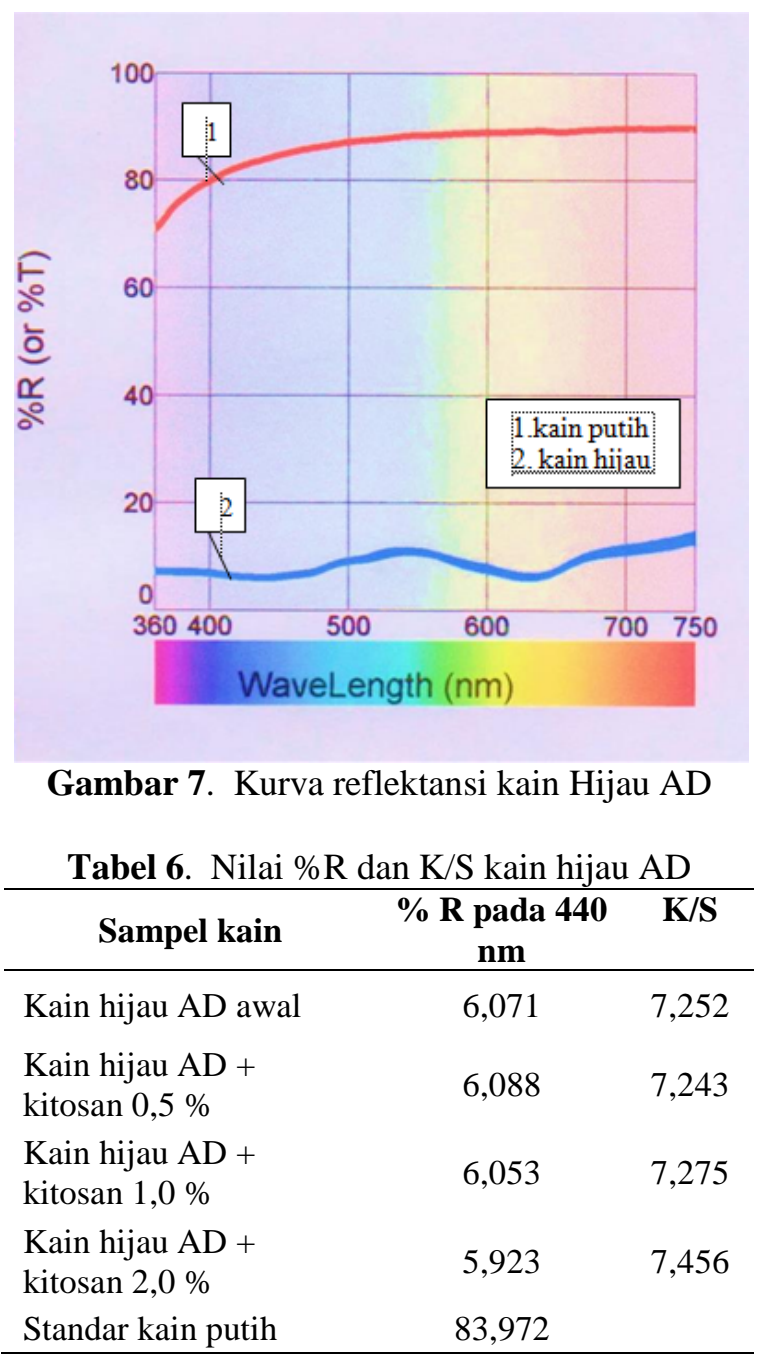

Dari kurva reflektansi pada Gambar 8 terlihat bahwa kurva \%R (\% reflektansi) setiap warna pada kain loreng yaitu warna coklat, coklat tua, hijau dan krem yang difiksasi kitosan dengan konsentrasi
$0,5 \%$ dan $1,0 \%$ hampir berhimpit dengan warna coklat, coklat tua, hijau dan krem dari kain loreng tanpa fiksasi kitosan. Bentuk kurva-kurva yang hampir berhimpit tersebut dengan karakteristik puncak pada panjang gelombang yang sama menunjukkan bahwa semuanya menghasilkan arah warna yang sama. Dari data pada Tabel 6 terlihat bahwa penambahan kitosan pada kain loreng untuk warna coklat, coklat tua, hijau dan krem pada kain loreng tersebut cenderung meningkatkan nilai $\mathrm{K} / \mathrm{S}$ yang berarti ketuaan warna cenderung meningkat. Hal ini cukup baik karena berarti pula proses fiksasi kitosan pada kain loreng tidak merusak warna warna coklat, coklat tua, hijau dan krem semula.

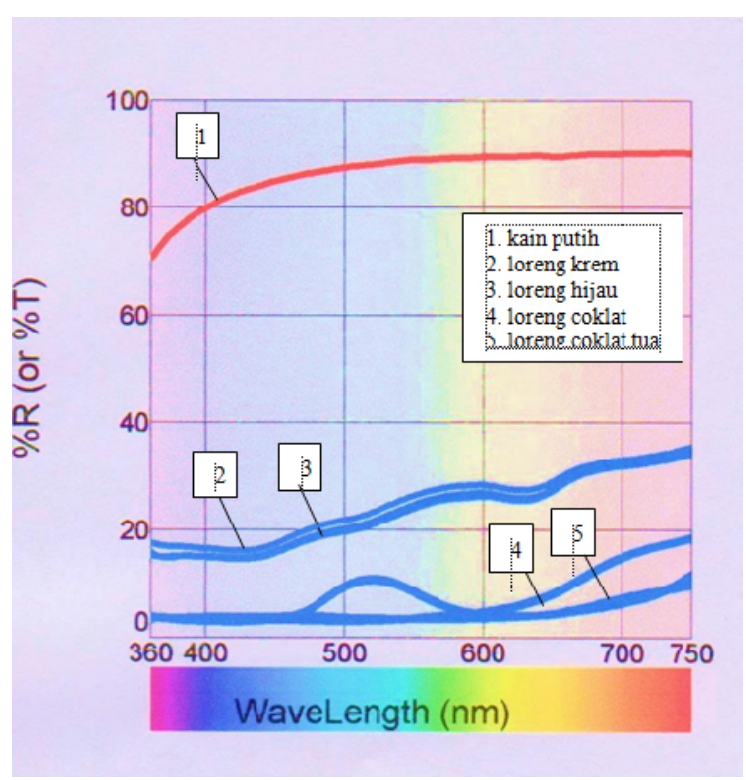

Gambar 8. Kurva reflektansi kain Loreng

Tabel 7. Nilai $\% \mathrm{R}$ dan K/S warna pada kain Loreng

\begin{tabular}{lccccccc}
\hline $\begin{array}{c}\text { Warna } \\
\text { pada } \\
\text { kain } \\
\text { loreng }\end{array}$ & $\begin{array}{c}\lambda \\
\mathrm{nm}\end{array}$ & Awal & + Ki $0,5 \%$ & + Ki $1,0 \%$ & Awal & + Ki $0,5 \%$ & + Ki 1,0\% \\
\cline { 3 - 8 } Coklat & 500 & 3,084 & 2,876 & 2,825 & 15,213 & 16,385 & 16,698 \\
$\begin{array}{l}\text { Coklat } \\
\text { tua }\end{array}$ & 570 & 3,505 & 3,360 & 3,285 & 13,268 & 13,814 & 14,153 \\
Hijau & 420 & 2,944 & 2,794 & 2,719 & 16,033 & 16,894 & 16,915 \\
Krem & 420 & 16,116 & 14,779 & 14,555 & 2,168 & 2,442 & 2,250 \\
\hline
\end{tabular}


Aplikasi kitosan sebagai zat anti bakteri pada kain poliester-selulosa dengan cara perendaman (Wiwin Winiati, Cica Kasipah, Wulan Septiani, Eva Novarini, Rizka Yulina)

\section{KESIMPULAN}

Fiksasi kitosan pada kain grey poliesterrayon 70:30 dan kain grey poliester-kapas 65:35 menunjukkan bahwa kitosan dengan gugus $-\mathrm{NH}_{2}$ sebagai gugus aktifnya telah berikatan dengan poliester-rayon dan poliester-kapas. Fiksasi kitosan pada kain hijau $\mathrm{AD}$ sebagai kain poliester-rayon 70:30 dan pada kain loreng sebagai kain poliesterkapas 65:35 yang telah di-printing, memberikan peningkatan serapan gugus $\mathrm{C}=\mathrm{N}$ dan gugus $\mathrm{C}-\mathrm{O}$, penurunan gugus $\mathrm{C}=\mathrm{O}$ dari ester yang menunjukkan terjadi ikatan poliester dengan kitosan, dan peningkatan serapan pada bilangan gelombang $1641 \mathrm{~cm}^{-1}$ yang menunjukkan terjadinya ikatan antara aldehid dan kitosan yang menunjukkan terjadinya fiksasi kitosan pada rayon maupun kapas. Fiksasi kitosan pada kain hijau AD dan kain loreng telah berhasil memberikan sifat antibakteri pada kain hijau $\mathrm{AD}$ dan kain loreng, tidak mengakibatkan terjadinya kerusakan pada serat poliester maupun serat rayon/kapas pada kain, dan tidak mengakibatkan kerusakan/penurunan ketuaan warna hijau malah makin banyak kitosan yang diberikan akan meningkatkan ketuaan warna hijau; dan tidak mengakibatkan kerusakan/ penurunan ketuaan setiap warna pada kain loreng yaitu warna coklat, coklat tua, hijau dan krem yang difiksasi kitosan dengan konsentrasi 0,5\% dan 1,0\% malah makin banyak kitosan yang diberikan akan meningkatkan ketuaan setiap warna pada kain loreng yaitu warna coklat, coklat tua, hijau dan krem tersebut.

\section{PUSTAKA}

${ }^{1}$ Xu, Y., McQueen, R., Wisner, W. (2013). A Preliminary Study on the Collection and Detection of Axillary Odor within Textiles. Journal of Textile and Apparel Technology and Management, 8 (3): 1-13

${ }^{2}$ Knittel, D., Schollmeyer, E. (2006). Chitosan for Permanent Antimicribial Finish on Textile. Lenzinger Berichte, 85: 124-130

${ }^{3}$ Ibrahim, N.A., and Hashem, M. (2010). Enhanching Antimicrobial Properties of Dyed and Finished Cotton/Polyester Fabric. AATCC Review, 56 64

${ }^{4}$ Gao Y., Cranston R. (2008). Recent Advances in Antimicrobial Treatment of Textiles. Textile Research Journal , 78 (1): 60-72.

${ }^{5}$ Ashraf, M., Dumont, F., Campagne, P., Perwuelz, A., Lerich, A., Chilib, N.E. (2014). Development of Antibacterial Polyester Fabric by Grouth of $\mathrm{ZnO}$ Nanorods. Journal of Egineered Fibers and Fabrics, 9 (1): 15-22

${ }^{6}$ Joshi, M., Ali, S. W., Purwar,R. (2009). Ecofriendly Antimicrobial Finishing of Textiles using
Bioactive Agent Based on Natural Products. Indian Journal of Fiber \& Textiles Research, 34: 295-304.

${ }^{7}$ Kumirska, J., Weinhold, M.X., Czerwicka, M., Kaczyñnski, Z., Bychowska, A., Btzozowski, K., Thöming, J., and Stepnowski, P. (2011). Influence of the Chemical Structure and Physicochemical Properties of Chitin-and Chitosan-based Materials on Their Biomedical Activity. In A.N. Laskovshi (eds.), Biomedical Engineering Trends in Material Science (2555). Intechopen.com

${ }^{8}$ Prashanth, K.V.H. and Tharanathan, R.N. (2007). Chitin/chitosan: Modifications and Their Unlimited Application Potential-An Overview. Trens in Food Science \& Technology, 18: 117 131.

${ }^{9}$ Mohanasrinivasan, V., et. al . (2013). Study on Heavy Metal Removal Efficiency and Antibacterial Activity of Chitosan Prepared from Shrimp Shell Waste. Springerlink.com open access

${ }^{10}$ Liu, N., et.al. (2006). Effect of MW and Concentration of Chitosan on Antibacterial Activity of Escherichia coli. Carbohydrate Polymers, $64: 60$ - 65

${ }^{11}$ Hafdani, F.N., and Sadeghinia, N. (2011). A Review on Application of Chitosan as a Natural Antimicrobial. World Academy of Science, Engineering and Technology, 50: 252-256

${ }^{12}$ Liu, S., Sun, G. (2011). Bio-functional Textiles. In V.T.Bartels (Eds.), Handbook of Medical Textiles (336-359). Woodhead Publishing Limited

${ }^{13}$ Ramadan, M.A., Samy, S., Abdulhady, M., and Hebeish, A.A. (2011). Eco-Friedly Pretreatment of Cellulosic Fabrics with Chitosan and Its Influence on Dyeing Efficiency, Natural Dyes. Emiye Akcakola Kumbasar (Ed.), In Tech

${ }^{14}$ Liu, S., Zhao, N., and Rudenja, S. (2010). Surface Interpenetrating Networks of Poly(ethylene terephthalate) and polyamides for Effective Biocidal Property. Macromol Chem Phys, 21: 286-296

${ }^{15}$ Chattopadhyay, D. And Inamdar, M.S. (2013). Improvement in Properties of Cotton Fabric through Synthesized Nano-Chitosan Application. Indian Journal of Fibre \& Textile Research, 38: 14-21

${ }^{16}$ Chang, Y.B., Tu, P.C., Wu, M.W., Hsiang, T., Hsu, S.H. (2008). A Study on Chitosan Modification of Polyester Fabrics by Atmospheric Pressure-Plasma and Its Antibacterial Effects. Fibers and Polymers, 9: 307-311

${ }^{17}$ Winiati, W., Kasipah, C., Yulina, R., Wahyudi, T., Mulyawan, A.S., Septiani, W. (2014). Fiksasi Kitosan pada Kain Kapas sebagai Antibakteri. Arena Tekstil, 29 (1): 25-36 
${ }^{18}$ Yulina, R., Winiati, W., Kasipah, C., Septiani, W., Mulyawan, A.S., Wahyudi, T. (2014). Pengaruh Berat Molekul terhadap Fiksasi Kitosan pada Kain Kapas sebagai Antibakteri. Arena Tekstil, 29 (2): 81-90

${ }^{19}$ Silverstein, R.M., Webster, F.X., Kiemle, D.J. (2005). Spectrometric Identification of Organic
${ }^{20}$ Compounds (7nd ed.). New York: JohnWiley \& Sons Inc.

${ }^{21}$ AATCC Test Method 147-1998, Antibacterial Activity Assessment of Textile Materials, AATCC Technical Manual, 2004. 